\title{
Absence of the European shore crab, Carcinus maenas, from the Fremantle marine area, Western Australia
}

\author{
Fred E. Wells ${ }^{1}$, Justin I. McDonald ${ }^{2}$ and Michael J. Travers ${ }^{3}$ \\ Western Australian Fisheries and Marine Research Laboratories, PO Box 20, North Beach, \\ Western Australia 6920, Australia. E-mail: molluscau@yahoo.com.au. \\ ${ }^{1}$ Research Associate, Field Museum of Natural History, Chicago, Illinois, U.S.A. Present addresses: 1. Enzer Marine \\ Environmental Consulting, PO Box 4176, Wembley, Western Australia 6014, Australia. \\ ${ }^{2}$ Ministry of Agriculture and Forestry, PO Box 2526, Wellington, New Zealand. \\ ${ }^{3}$ Australian Institute of Marine Science, Botany Building, University of Western Australia, Crawley, \\ Western Australia 6009, Australia.
}

The European shore crab, Carcinus maenas (Linnaeus, 1758) is an invasive species that was originally distributed along the coast of North Africa and Europe. It has been widely introduced to the east and west coasts of North America, South America, Australia, Asia, and South Africa (Ahyong 2005; Klassen and Locke 2007). The crab is a voracious feeder that consumes a wide variety of organisms. It is destructive and is regarded as a danger to commercial fisheries for molluscs, crustaceans and scalefish (Klassen and Locke 2007). The ecology of Australian populations of C. maenas has been studied by Thresher et al. (2003) and Ross et al. (2004). Concerns over the potential adverse effects of $C$. maenas led to the first international workshop on the demography, impacts and management of introduced populations of the European crab (Thresher 1997).

The first introduction of C. maenas in Australia has long been considered to have been to Victoria in 1900 (Fulton and Grant 1902) where the crab is thought to have arrived on the hull of a vessel or in discarded solid ballast. The species has been recorded from Gulf St Vincent and Coorong, South Australia, eastern Tasmania, and from Port Philip Bay, Victoria to Narooma in southern New South Wales. Ahyong (2005) recently extended the range along the NSW coast northwards as far as Sydney, based on specimens he collected and on personal observations. Specimens in the Macleay Museum had been collected from the Sydney area prior to 1891 but had been disregarded (Stephenson and Campbell 1960), probably because the Sydney area was far outside the known northern limit of the species. Ahyong (2005) believes the locality for the Macleay Museum specimens is valid meaning $C$. maenas arrived in Sydney earlier than in Melbourne.

The European shore crab is shown as a species of concern by the Western Australian Department of
Fisheries (DOF 2000) and is one of the target species for introduced marine pest monitoring listed by the National Introduced Marine Pests Coordination Group (NIMPCG 2006). In Western Australia, C. maenas is known from a single mature male $7.1 \mathrm{~cm}$ in carapace width collected by "Smith" at Blackwall Reach in the Swan River in 1965 (Zeidler 1978) (WAM C14833; Figure 1). The record was subsequently cited by Furlani (1996), Hass and Jones (2000), Pollard and Hutchings (1990), and Ahyong (2005). However, in a marine pest survey report for the port of Albany, CRIMP (1997) reported the Swan River specimen, but stated that no populations appear to have been established. The subsequent survey of the Port of Fremantle (CRIMP 2000) failed to find any specimens. However, the CRIMP survey was of the port area and included only the lower reaches of the Swan River. In their compilation of information on introduced marine species in WA, Huisman et al. (2008) listed C. maenas as not occurring in Western Australia.

As C. maenas is considered to be a high-risk species (DOF 2000), it is important to know if it has in fact been established in the Fremantle marine area. In late September and early October 2007 a detailed search was undertaken of 43 sites to search for four introduced species. This included Carcinus maenas, the European fanworm, Sabella spallanzanii (Gmelin, 1791), recorded in Cockburn Sound and Fremantle by Clapin and Evans (1995); the Asian date mussel Musculista senhousia (Benson in Cantor, 1842) recorded in the Swan River and at Fremantle by Slack-Smith and Brearley (1987); and the eastern Australian scallop Scaeochlamys lividus (Lamarck, 1819) reported from Fremantle and Cockburn Sound by Morrison and Wells (2008). Results on $M$. senhousia are presented elsewhere (McDonald and Wells 2009), and a general survey report is available (McDonald and Wells 2008). 
The search covered the full range of sites in the estuarine reaches of the Swan River, Fremantle inner harbour at the mouth of the Swan, Rouse Head, Owen Anchorage, and Cockburn Sound and also included a site in Warnbro Sound (Table 1, Figure 2). Subtidal visual searches were conducted by a team of two divers. Divers entered the water together and searched the shore or pilings as they descended to the seafloor where they would space themselves approximately 1-2 $\mathrm{m}$ apart, depending upon visibility, and available space. The divers then proceeded along the seafloor searching for all four species or any other species that could be mistaken for one of the target species. The search area thus included all available depths from the surface to the bottom. The region is microtidal, with a maximum tidal range over a year of about $1 \mathrm{~m}$; the tidal variation on most days is about $0.3-0.4 \mathrm{~m}$ (Hodgkin and DiLollo 1958), so the study included the full tidal range. The search included Blackwall Reach, where the single known specimen of C. maenas was collected in Western Australia, and sites both further up and lower down on the Swan River.

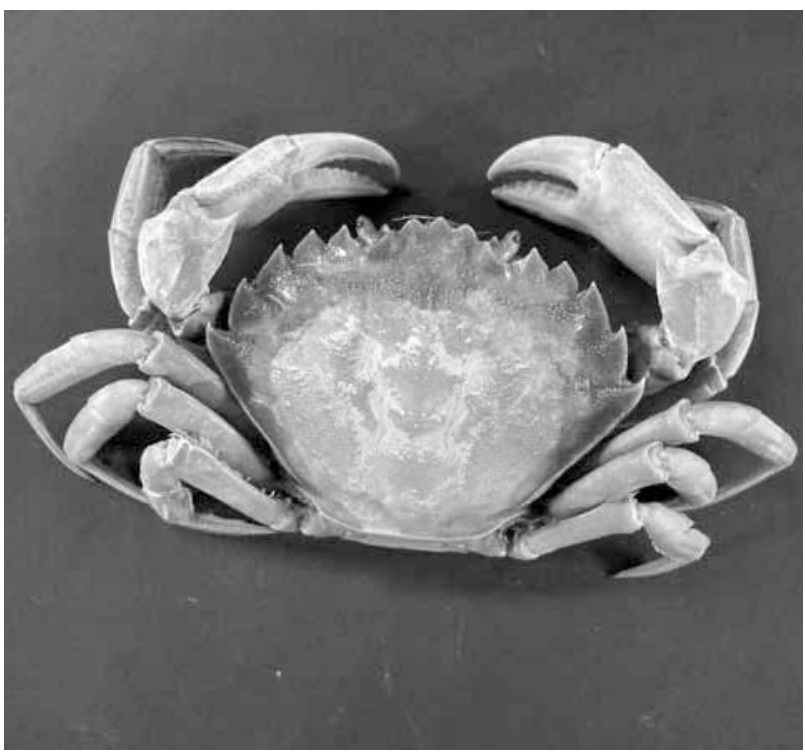

Figure 1 The European shore crab, Carcinus maenas from Blackwall Reach, Swan River, Western Australia (WAM C14833). Photo courtesy of Andrew Hosie.

Table 1 Sites targeted in the 2007 survey of the Fremantle marine area for introduced species. CR, Canning River; CS, Cockburn Sound; FIH, Fremantle inner harbour; LSR, Lower Swan River; PW, Perth Water; USR, Upper Swan River; WS, Warnbro Sound.

\begin{tabular}{|c|c|c|c|c|c|}
\hline $\begin{array}{c}\text { Site } \\
\text { Number }\end{array}$ & Area & Location & $\begin{array}{c}\text { Site } \\
\text { Number }\end{array}$ & Area & Location \\
\hline 1 & WS & Saxon Ranger wreck & 23 & CS & Success channel marker B \\
\hline 2 & CS & Calista channel, port marker F & 24 & CS & Success Channel marker F \\
\hline 3 & CS & Challenger Passage lead marker 2 & 25 & CS & Wreck of the D9 \\
\hline 4 & CS & Garden Island Armaments Jetty & 26 & $\mathrm{FIH}$ & Fremantle Berth 2 \\
\hline 5 & CS & Garden Island, Navy Boats Harbour & 27 & $\mathrm{FIH}$ & Fremantle Berth 4 \\
\hline 6 & CS & Kwinana Bulk Jetty front & 28 & $\mathrm{FIH}$ & Fremantle Berth 5 \\
\hline 7 & CS & Kwinana Bulk Jetty shallow part & 29 & $\mathrm{FIH}$ & Fremantle Traffic Bridge (north side) \\
\hline 8 & CS & Kwinana Bulk Terminal 2 & 30 & LSR & Blackwall Reach \\
\hline 9 & CS & North Mole wreck & 31 & LSR & Chidley Point \\
\hline 10 & CS & Northern Lead S \& P channel & 32 & LSR & Keanes Jetty \\
\hline 11 & CS & Old submarine netting & 33 & LSR & Matilda Bay \\
\hline 12 & CS & Rockingham L jetty & 34 & LSR & Rocky Bay Channel \\
\hline 13 & CS & Rockingham middle jetty & 35 & LSR & Royal Freshwater Bay Yacht Club \\
\hline 14 & CS & Rockingham CS wreck front dive store & 36 & $\mathrm{CR}$ & Canning Bridge (SW Side) \\
\hline 15 & CS & Rous Harbour barge & 37 & CR & Deepwater Point \\
\hline 16 & CS & Southern flats 1 & 38 & $\mathrm{CR}$ & Shelley Bridge \\
\hline 17 & CS & Southern flats 2 & 39 & PW & Sir James Mitchell Park (South Perth) \\
\hline 18 & CS & Southern flats 3 & 40 & USR & Clarkson Reserve (Maylands) \\
\hline 19 & CS & Southern flats 4 & 41 & USR & Fish Market Reserve (Guildford) \\
\hline 20 & CS & Southern flats 5 & 42 & USR & Garrett Road Bridge (AP Hinds Reserve) \\
\hline 21 & CS & Stirling channel marker 1 & 43 & USR & Trinity College Foreshore \\
\hline 22 & CS & Success channel marker 2 & & & \\
\hline
\end{tabular}




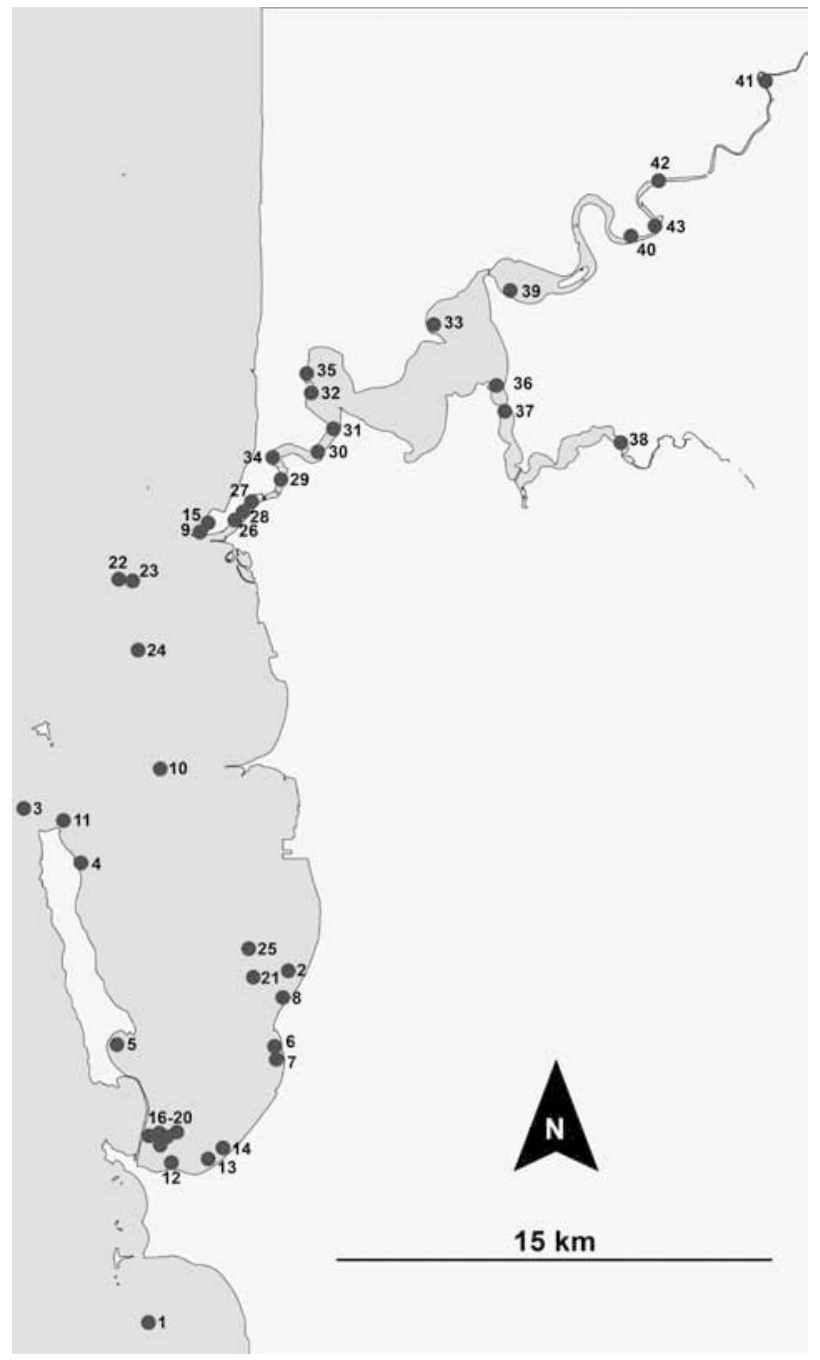

Figure 2 Sites surveyed for the European shore crab, Carcinus maenas, in the Fremantle marine area in September and October 2007.

No C. maenas were found in the present survey, which supports the findings in the CRIMP (2000) survey of a more restricted area. As surveys of this study cover a relatively large spatial and temporal sphere it is concluded that the species has not become established in the Fremantle marine area.

\section{ACKNOWLEDGEMENTS}

This project was funded by a Natural Heritage Trust grant (project no. 053085). We thank Dr Andrew Hosie, Western Australian Museum, for confirming the identification and photographing the WAM specimen of C. maenas and Emily Gates for assistance in the fieldwork.

\section{REFERENCES}

Ahyong, S.T. (2005). Range extension of two invasive crab species in eastern Australia: Carcinus maenas (Linnaeus) and Pyromaia tuberculata (Lockington). Marine Pollution Bulletin 50: 460-462.
Clapin, G. and Evans, D.R. (1995). The status of the introduced marine fanworm Sabella spallanzanii in Western Australia: a preliminary investigation. CSIRO Technical Report, No. 2. Division of Fisheries, CSIRO: Hobart, Australia.

CRIMP. (1997). Introduced species survey, Port of Albany, Western Australia. Centre for Research on Introduced Marine Pests, Division of Fisheries, CSIRO: Hobart, Australia.

CRIMP. (2000). Introduced species survey final report, Fremantle, Western Australia. Centre for Research on Introduced Marine Pests, Division of Fisheries, CSIRO: Hobart, Australia.

Department of Fisheries (DOF) (2000). Introduced marine aquatic invaders. Western Australian Department of Fisheries: Perth, Australia.

Fulton, S.W. and Grant, F.E. (1902). Some little known Victorian decapod Crustacea with description of a new species. Transactions of the Royal Society of Victoria 14: 55-64.

Furlani, D.M. (1996). A guide to the introduced marine species in Australian waters. Centre for Research on Introduced Marine Pests, Division of Fisheries, CSIRO: Hobart, Tasmania, Division of Fisheries Technical Report No. 5.

Gmelin, J.F. (1791). Caroli a Linne systeme naturae per regna tria naturae. $13^{\text {th }}$ edition. G.E. Brev: Leipzig, Austria.

Hass, C.G. and Jones, D.S. (1999). Marine introductions to Western Australia, with a focus on crustaceans. Pp. 37-44. In: Kesby, J.A., Stanley, J.M., McLean, R.F. and Olive, L.J. (eds), Geodiversity: readings in Australian geography at the close of the $20^{\text {th }}$ century. Special Publication Series No. 6, School of Geography and Oceanography, University College, Australian Defence Force Academy, Canberra, Australia.

Hodgkin, E.P. and DiLollo, V. (1958). Tides of southwestern Australia. Journal of the Royal Society of Western Australia 41: 42-51.

Huisman, J.M., Jones, D.S., Wells, F.E., and Burton, T. (2008). Marine introductions into Western Australian waters. Records of the Western Australian Museum 25: 1-44.

Klassen, G. and Locke, A. (2007). A biological synthesis of the European green crab, Carcinus maenas. Canadian Manuscript Reports of Fisheries and Aquatic Sciences 2818: 1-75.

Lamarck, J.P.P.A. de M. de. (1819). Histoire naturelle des Animaux sans Vertébres. Verdiere: Paris, France.

Linnaeus, C. (1758). Systemae naturae per Regna tria Naturae. Regnum Animale. Edition 10, Holmiae, Sweden.

McDonald, J.I. and Wells, F.E. (2009). Results of a 2007 survey of the Swan River region for four introduced marine species. Department of Fisheries, Western Australia, Fisheries Research Report 189: 1-24.

McDonald, J.I. and Wells, F.E. (2009). The apparent demise of the Asian date mussel (Musculista senhousia): or using acts of god as an eradication tool. Biological Invasions 12: 715-719.

Morrison, H. and Wells, F.E. (2008). Colonisation of Fremantle Harbour and Cockburn Sound, Western Australia by the eastern Australian scallop Scaeochlamys livida (Lamarck, 1819). Molluscan Research 28: 107-110. 
NIMPCG. (2006). Australian marine pests monitoring guidelines: Version 1. National Introduced Marine Pests Coordination Group, Department of Agriculture, Fisheries and Forestry: Canberra, Australia.

Pollard, D.A. and Hutchings, P.A. (1990). A review of exotic marine organisms introduced to the Australasian region. II. Invertebrates and algae. Asian Fisheries Science 3: 223-250.

Ross, D.J., Johnson, C.R., Hewitt, C.L. and Ruiz, G.M. (2004). Interaction and impacts of two introduced species on a soft-sediment marine assemblage in SE Tasmania. Marine Biology 144: 747-756.

Slack-Smith, S.M. and Brearley, A. (1987). Musculista senhousia (Benson, 1842); a mussel recently introduced into the Swan River estuary, Western Australia (Mollusca: Mytilidae). Records of the Western Australian Museum 13: 225-230.

Stephenson, W. and Campbell, B.M. (1960). The Australian portunids (Crustacea: Portunidae). IV
Remaining genera. Australian Journal of Marine and Freshwater Research 11: 73-122.

Thresher, R.E. (1997). Proceedings of the first international workshop on the demography, impacts and management of introduced populations of the European crab, Carcinus maenas. CSIRO Division of Marine Research, Hobart, Tasmania, CRIMP Technical Report Number 11.

Thresher, R., Proctor, C., Ruiz, G., Gurney, R., MacKinnon, C., Walton, W., Rodriguez, L., and Bax, N. (2003). Invasion dynamics of the European shore crab, Carcinus maenas, in Australia. Marine Biology 142: 867-876.

Zeidler, W. (1978). Note on the occurrence of the European shore crab Carcinus maenas (Linn., 1758) in Australia. The South Australian Naturalist 53: 11-12.

Manuscript received 26 March 2009; accepted 19 May 2009. 